\title{
Peran Kebijakan Dividen dalam Memediasi Profitabilitas dan Kebijakan Pendanaan Terhadap Nilai Perusahaan
}

\author{
Desire Nur Addin Afeeanti ${ }^{1}$, Indah Yuliana ${ }^{2}$ \\ 1, 2 Universitas Islam Negeri Maulana Malik Ibrahim Malang \\ 1desirenaa@ymail.com, 2indahoty@manajemen.uin-malang.ac.id \\ *Penulis Korespondensi
}

\begin{abstract}
This study examines the role of dividend policy in mediating profitability and leverage on firm value. The method used in this research is Structural Equation Modeling-Partial Least Square (SEM-PLS) to test the relationship between variables. This study uses data on annual report of go-public companies in 2014-2018 period. ROE and ROA are independent variables DER and DAR are independent variables While PER and PBV are the dependent variables and DPR and DY are intervening variables. This study resulted in profitability and leverage has positive and significant effect, but the dividend policy negative and no significant effect on firm value. Profitability has positive and significant effect, but leverage has a significant negative effect on dividend policy. Dividend policy has not been able to mediate between profitability and leverage on firm value.
\end{abstract}

Keywords: profitability; leverage; firm value; dividend policy

\begin{abstract}
Abstrak
Penelitian ini menguji peran kebijakan dividen dalam memediasi profitabilitas dan kebijakan pendanaan terhadap nilai perusahaan. Metode yang digunakan dalam penelitian ini Structural Equation ModelingPartial Least Square (SEM-PLS) untuk menguji hubungan antar variabel. Penelitian ini menggunakan data laporan keuangan perusahaan go-public periode 2014-2018. ROE dan ROA adalah variabel independen (X1), DER dan DAR adalah variabel independen (X2). Sedangkan PER dan PBV adalah variabel dependen dan DPR dan DY adalah variabel intervening. Penelitian ini menghasilkan profitabilitas dan kebijakan pendanaan berpengaruh secara positif dan signifikan, namun kebijakan dividen berpengaruh secara negatif dan tidak signifikan terhadap nilai perusahaan. Profitabilitas berpengaruh secara positif dan signifikan, namun kebijakan pendanaan berpengaruh secara negatif signifikan terhadap kebijakan dividen. Kebijakan dividen belum mampu memediasi antara profitabilitas dan kebijakan pendanaan terhadap nilai perusahaan.
\end{abstract}

Kata kunci: profitabilitas; kebijakan pendanaan; nilai perusahaan; kebijakan dividen

\section{Cara Mengutip:}

Afeeanti, D. N. A., Yuliana, I. (2020). Peran Kebijakan Dividen dalam Memediasi Profitabilitas dan Kebijakan Pendanaan terhadap Nilai Perusahaan. Esensi: Jurnal Bisnis dan Manajemen. Vol. 10 (2): 161-172. DOI: https://doi.org/10.15408/ess.v10i2.16165 


\section{PENDAHULUAN}

Kinerja perusahaan dapat dilihat dari nilai perusahaan. Nilai perusahaan yang tinggi mencerminkan pengelola perusahaan mampu memanfaatkan segala sumber daya yang terdapat didalamnya. Sebelum membeli saham penting untuk mengamati nilai perusahaan karena berbanding lurus dengan harga saham. Semakin tinggi harga saham maka akan semakin tinggi pula nilai perusahaan (Fuad \& Wandari, 2018). Dengan mengetahui nilai perusahaan, maka investor dapat mengidentifikasi saham-saham mana saja yang sedang undervalued atau overvalued untuk dijadikan salah satu faktor menentukan keputusan investasi. Indikator nilai perusahaan dalam penelitian ini yaitu Price Earning Ratio (PER) adalah rasio yang membandingkan harga pasar per lembar saham dengan laba per lembar saham dan Price to Book Value (PBV) adalah rasio yang membandingkan harga pasar per lembar saham dengan nilai buku per lembar saham.

Penelitian ini akan membahasa tiga faktor yang dapat mempengaruhi nilai perusahaan yaitu profitabilitas, kebijakan pendanaan, dan kebijakan dividen. Profitabilitas berfungsi sebagai penunjang kelancaran kegiatan operasional yang juga sebagai daya tarik investor untuk menanamkan modalnya. Semakin besar profitabilitas yang dihasilkan oleh suatu perusahaan, maka akan semakin besar pula nilai perusahaan tersebut. Profitabilitas yang tinggi menandakan peluang perusahaan yang baik sehingga investor akan merespon positif sinyal tersebut dan nilai perusahaan akan meningkat (Sujoko \& Soebiantoro, 2007). Indikator profitabilitas dalam penelitian ini yaitu Return On Equity (ROE) adalah rasio yang membandingkan laba bersih dengan ekuitas dan Return On Assets (ROA) adalah rasio yang membandingkan laba bersih dengan total aset.

ROE berpengaruh secara positif dan signifikan terhadap nilai perusahaan (Hidayat, 2019; Hidayati, 2010; Indriawati dkk., 2018). ROE yang turun menyebabkan nilai PBV turun juga. Rasio ROE merupakan indikator kapabilitas perusahaan dalam pengembalian atas modal sendiri yang juga bisa dialokasikan ke pemegang saham. Sehingga semakin tinggi rasio ROE akan mengakibatkan semakin tinggi permintaan saham dan secara langsung dapat meningkatkan nilai perusahaan. Hasil lain juga membuktikan bahwa ROA berpengaruh secara positif dan signifikan terhadap PBV (Aditya \& Supriyono, 2015). Namun, penelitian lain menemukan hasil yang berbeda, yaitu profitabilitas tidak berpengaruh terhadap nilai perusahaan (Pratiwi \& Mertha, 2017).

Faktor kedua penentu nilai perusahaan adalah kebijakan pendanaan. Kebijakan pendanaan adalah kebijakan atas pembiayaan oleh utang (Fahmi, 2014). Fungsi utang sendiri dalam perusahaan cukup besar yakni untuk menambah modal operasional. Menurut (Brigham \& Houston, 2009) penggunaan utang juga berdampak pada harga saham perusahaan. Semakin besar utang, maka akan menaikkan nilai perusahaan. Perusahaan dengan tingkat utang yang tinggi akan menaikkan laba per lembar saham, sehingga menyebabkan naiknya harga saham perusahaan yang diikuti dengan kenaikan nilai perusahaan. (Rakhimsyah \& Gunawan, 2011) menambahkan DER yang tinggi menunjukkan besarnya jumlah utang. Indikator kebijakan pendanaan dalam penelitian ini yaitu Debt to Equity Ratio (DER) adalah rasio yang membandingkan total utang dengan ekuitas dan Debt to Assets Ratio (DAR) adalah rasio yang membandingkan total utang dengan total aset. 
Kebijakan pendanaan dapat menyebabkan pertumbuhan nilai perusahaan karena dapat meminimalkan konflik keagenan (Dananjaya \& Mustanda, 2016; Jariah, 2016; Pratiwi \& Mertha, 2017). Lebih lanjut, peningkatan utang diartikan bahwa perusahaan memiliki potensi di masa yang akan datang. Utang dapat mengurangi beban pajak dan digantikan dengan beban bunga. Sehingga perusahaan lebih memilih untuk membayar bunga atas pinjaman dengan tujuan untuk mengurangi pajak yang dapat bermanfaat bagi pemegang saham (Mubyarto \& Khairiyani, 2019). Namun, hasil lain membuktikan bahwa leverage tidak berpengaruh secara signifikan terhadap nilai perusahaan (Hidayat, 2019; Hidayati, 2010; Supriyanah \& Ghoniyah, 2015). Selain itu, (Utomo, 2019) dalam penelitiannya juga menghasilkan bahwa keputusan pendanaan berpengaruh positif namun tidak signifikan terhadap nilai perusahaan.

Dividen adalah profitabilitas yang diberikan kepada para pemegang saham yang bersumber dari kapabilitas emiten mencetak laba bersih dari satu periode operasionalnya (Hadi, 2013). Kebijakan dividen merupakan bagian dari profitabilitas yang diperoleh perusahaan dan dibayarkan kepada pemegang saham. Oleh karena itu, dividen merupakan hal yang diharapkan pemegang saham dari profitabilitas perusahaan. Besar kecilnya jumlah dividen yang diberikan oleh perusahaan akan sangat mempengaruhi pencapaian dan kesejahteraan pemegang saham (Gitosudarmo \& Basri, 2014). Meningkatnya dividen akan memberi dampak positif terhadap harga saham yang juga akan berdampak positif terhadap nilai perusahaan (Hidayati, 2010). (Rakhimsyah \& Gunawan, 2011) menambahkan semakin tinggi rasio pembayaran DPR akan mengakibatkan nilai perusahaan semakin tinggi pula. Indikator kebijakan dividen dalam penelitian ini yaitu Dividend Payout Ratio (DPR) adalah rasio yang membandingkan total dividen dengan laba bersih dan Dividen Yield (DY) adalah rasio yang membandingkan dividen per lembar saham dengan harga per lembar saham.

Kebijakan dividen berpengaruh secara positif dan signifikan terhadap nilai perusahaan (Aditya \& Supriyono, 2015; Mubyarto \& Khairiyani, 2019; Priyanto, 2016; Utomo, 2019). Hasil lain menunjukkan bahwa kebijakan dividen berpengaruh secara positif namun tidak signifikan terhadap nilai perusahaan (Dananjaya \& Mustanda, 2016). Hasil berbeda ditemukan bahwa kebijakan dividen tidak berpengaruh terhadap nilai perusahaan (Hauteas \& Muslichah, 2019; Rakhimsyah \& Gunawan, 2011). Pengaruh tidak langsung kebijakan dividen mampu memediasi keputusan pendanaan terhadap nilai perusahaan secara positif dan signifikan (Utomo, 2019). Berbeda dengan penelitian yang menghasilkan kebijakan dividen tidak dapat memediasi pengaruh profitabilitas dan kebijakan pendanaan terhadap nilai perusahaan (Aditya \& Supriyono, 2015; Supriyanah \& Ghoniyah, 2015). Hasil yang tidak konsisten dari penelitian terdahulu merupakan celah bagi peneliti untuk meneliti lebih lanjut mengenai pengaruh profitabilitas dan kebijakan pendanaan terhadap nilai perusahaan melalui kebijakan dividen dengan tujuan penelitian adalah untuk mengetahui peran kebijakan dividen dalam memediasi profitabilitas dan kebijakan pendanaan terhadap nilai perusahaan.

\section{METODE}

Jenis penelitian ini merupakan penelitian kuantitatif deskriptif. Penelitian ini menggunakan data sekunder yang berjumlah 27 perusahaan yang tercatat pada Bursa 
Efek Indonesia (BEI) sektor perdagangan, jasa dan investasi periode 2014-2018 di akses melalui website resmi Bursa Efek Indonesia (BEI) www.idx.co.id. Penelitian ini menggunakan variabel profitabilitas, kebijakan pendanaan sebagai variabel independen, nilai perusahaan sebagai variabel dependen dan kebijakan dividen sebagai variabel mediasi. Analisis data dalam penelitian ini menggunakan metode Structural Equation Modeling-Partial Least Square (SEM-PLS) untuk menguji hubungan antar variabel dengan ketujuh hipotesis secara lebih kompleks dalam penelitian ini. Setiap hipotesis akan diuji menggunakan software SmartPLS 3.2.9 untuk menguji hubungan antar variabel dan mengetahui peran kebijakan dividen dalam memediasi profitabilitas dan kebijakan utang terhadap nilai perusahaan.

\section{HASIL DAN PEMBAHASAN}

Validitas Konvergen (Convergent Validity) diuji berdasarkan hubungan antara indikator terhadap konstruk, nilai outer loading dikatakan sangat baik apabila $>0.70$ dan dikatakan cukup apabila berada di rentang 0.50-0.60 (Mubyarto \& Khairiyani, 2019).

\section{Gambar 1. Hasil Uji Convergent Validity 1}

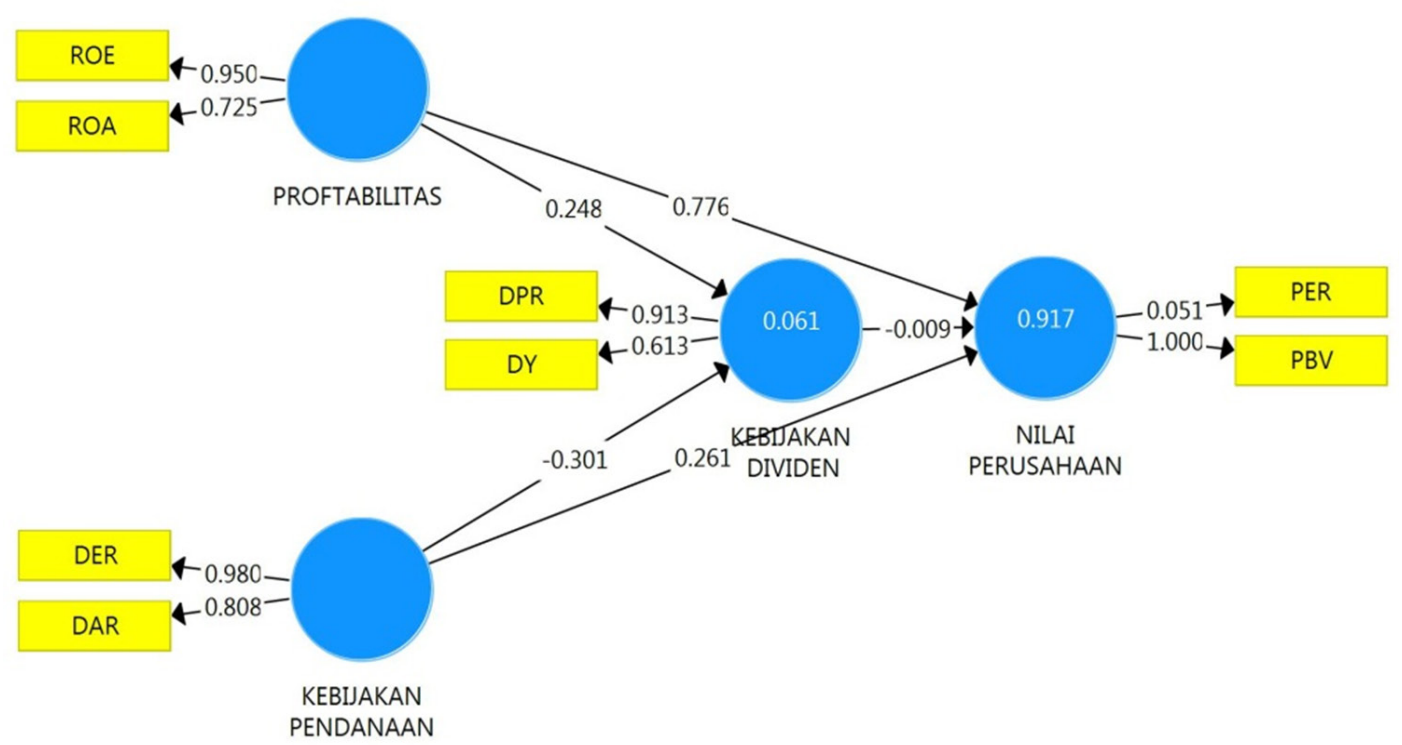

Sumber: data diolah (2020)

Gambar 1 menerangkan bahwa ROE dan ROA mampu merefleksikan profitabilitas dengan nilai outer loadings masing-masing sebesar 0.950 dan 0.725 . Kebijakan pendanaan dijelaskan oleh dua indikator yaitu DER dan DAR senilai 0.980 dan 0.808. Kebijakan dividen dijelaskan oleh DPR senilai 0.913. PBV mampu merefleksikan nilai perusahaan dengan nilai outer loadings sebesar 1.000. PER dan DY harus dihapus karena $<0.70$. PER belum mampu merefleksikan nilai perusahaan karena fluktuasi harga wajar saham tidak sama dengan fluktuasi laba bersih. Sedangkan DY belum mampu merefleksikan kebijakan dividen karena sebagian besar perusahaan sampel pada sektor Perdagangan, Jasa dan Investasi periode 2014-2018 memiliki nilai DY di bawah rata-rata. 
Hasil uji convergent validity pertama menunjukkan bahwa terdapat beberapa indikator yang memiliki nilai kurang dari 0.70 sehingga pada aplikasi SmartPLS menunjukkan warna merah yang memiliki arti bahwa indikator tersebut tidak bekerja pada model pengukurannya (Bimo, 2013). Gambar 2 menerangkan bahwa setelah menghapus dua indikator yang tidak mampu merefleksikan variabel latennya, maka terlihat semua indikator telah lulus uji convergent validity. Hasil uji pada Gambar 2 menerangkan bahwa kebijakan dividen hanya direfleksikan oleh DPR dan nilai perusahaan hanya direfleksikan oleh PBV.

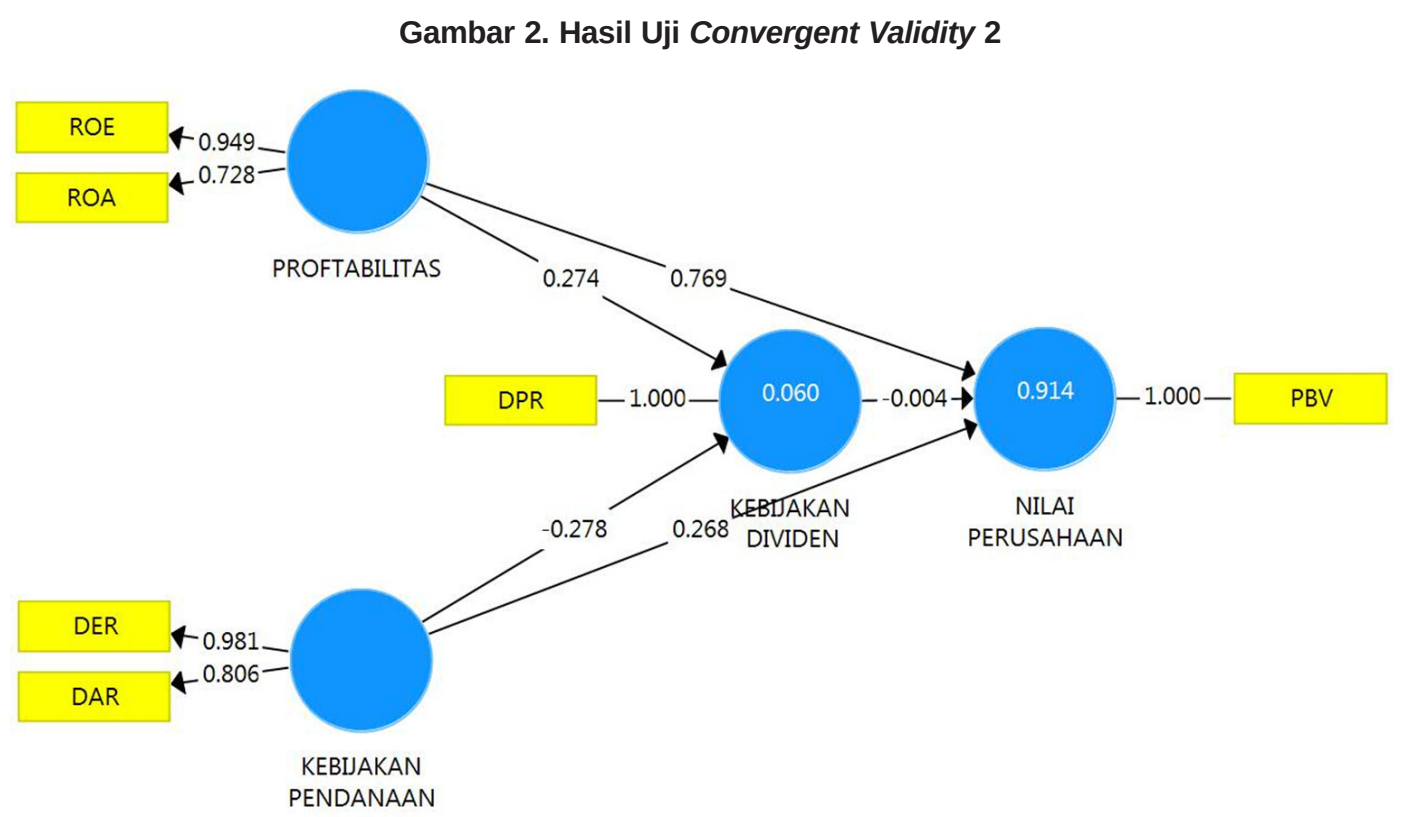

Sumber: data diolah (2020)

Construct Reliability and Validity adalah pengujian untuk mengukur kehandalan suatu konstruk (Juliandi, 2018). Variabel konstruk dikatakan reliabel atau konsisten apabila nilai Cronbach's Alpha >0.6 (Sujarweni, 2014). Hasil uji Cronbach's Alpha pada Tabel 1 menerangkan bahwa keseluruhan konstruk reliabel dan tingkat konsistensi yang tinggi karena memiliki nilai Composite Reliability: >0.6 yaitu 0.832, 0.891, 1.000 dan 1.000; dengan nilai Cronbach's Alpha $>0.6$ yaitu 0.643, 0.806, 1.000 dan 1.000, dan dengan nilai Average Variance Extraxted (AVE): $>0.5$ yaitu $0.715,0.805,1.000$ dan 1.000 .

Hasil uji inner model pada Gambar 2 di dapat nilai R-Square kebijakan dividen sebesar 0.060 yang memiliki makna besar pengaruh variabel profitabilitas dan kebijakan pendanaan terhadap kebijakan dividen sebesar 6\%. Sedangkan nilai R-Square pada variabel nilai perusahaan sebesar 0.914 yang memiliki makna besar pengaruh variabel profitabilitas, kebijakan pendanaan dan kebijakan dividen terhadap nilai perusahaan sebesar $91.4 \%$ dan sisanya dijelaskan oleh variabel lain diluar variabel tersebut 
Tabel 1. Uji Outer Model, Uji Validity, dan Uji Reliability

\begin{tabular}{|c|c|c|c|c|c|}
\hline Konstruk & Item & $\begin{array}{c}\text { Outer } \\
\text { Loadings }\end{array}$ & $\begin{array}{c}\text { Cronbach's } \\
\text { Alpha }\end{array}$ & $\begin{array}{l}\text { Composite } \\
\text { Reliability }\end{array}$ & AVE \\
\hline \multirow{2}{*}{ Profitabilitas } & ROE & 0.949 & \multirow{2}{*}{0.643} & \multirow{2}{*}{0.832} & \multirow{2}{*}{0.715} \\
\hline & ROA & 0.728 & & & \\
\hline \multirow{2}{*}{ Kebijakan Pendanaan } & DER & 0.981 & \multirow{2}{*}{0.806} & \multirow{2}{*}{0.891} & \multirow{2}{*}{0.805} \\
\hline & DAR & 0.806 & & & \\
\hline Nilai Perusahaan & PBV & 1.000 & 1.000 & 1.000 & 1.000 \\
\hline Kebijakan Dividen & DPR & 1.000 & 1.000 & 1.000 & 1.000 \\
\hline
\end{tabular}

Sumber: data diolah (2020)

Tabel 2. Path Coefficients

\begin{tabular}{llcccc}
\hline & $\begin{array}{c}\text { Original } \\
\text { Sampel } \\
(\mathbf{O})\end{array}$ & $\begin{array}{c}\text { Sample } \\
\text { Mean } \\
(\mathbf{M})\end{array}$ & $\begin{array}{c}\text { Standard } \\
\text { Deviation } \\
\text { (STDEV) }\end{array}$ & T-Statistics & P-Values \\
\hline $\begin{array}{l}\text { Profitabilitas } \rightarrow \\
\text { Nilai Perusahaan }\end{array}$ & 0.769 & 0.776 & 0.064 & 12.061 & 0.000 \\
\hline $\begin{array}{l}\text { Kebijakan Pendanaan } \rightarrow \\
\text { Nilai Perusahaan }\end{array}$ & 0.268 & 0.242 & 0.080 & 3.334 & 0.001 \\
\hline $\begin{array}{l}\text { Profitbailitas } \rightarrow \\
\text { Kebijakan Dividen }\end{array}$ & 0.274 & 0.277 & 0.109 & 2.529 & 0.012 \\
\hline $\begin{array}{l}\text { Kebijakan Pendanaan } \rightarrow \\
\text { Kebijakan Dividen }\end{array}$ & -0.278 & -0.256 & 0.113 & 2.460 & 0.014 \\
\hline $\begin{array}{l}\text { Kebijakan Dividen } \rightarrow \\
\text { Nilai Perusahaan }\end{array}$ & -0.004 & 0.029 & 0.074 & 0.059 & 0.953 \\
\hline $\begin{array}{l}\text { Profitabilitas } \rightarrow \\
\text { Nilai Perusahaan }\end{array}$ & -0.001 & 0.005 & 0.022 & 0.054 & 0.957 \\
\hline $\begin{array}{l}\text { Kebijakan Pendanaan } \rightarrow \\
\text { Nilai Perusahaan }\end{array}$ & 0.001 & -0.005 & 0.017 & 0.071 & 0.943 \\
\hline
\end{tabular}

Sumber: data diolah (2020)

$\mathrm{H}_{1}$ : Profitabilitas berpengaruh terhadap Nilai Perusahaan

Tabel 2 menunjukkan bahwa antara profitabilitas terhadap nilai perusahaan memiliki nilai Original Sample sebesar 0.769, nilai T-Statistik sebesar $12.061>$ nilai T-tabel (T-tabel signifikansi $5 \%=1.978$ ) dan nilai P-Value sebesar 0.000, maka dapat diartikan profitabilitas berpengaruh secara positif dan signifikan terhadap nilai perusahaan sehingga $\mathrm{H}_{1}$ diterima. $\mathrm{H}_{2}$ : Kebijakan Pendanaan berpengaruh terhadap Nilai Perusahaan

Nilai Original Sample sebesar 0.268, T-Statistik sebesar $3.334>$ nilai T-tabel, dan P-Value sebesar 0.001 antara kebijakan pendanaan terhadap nilai perusahaan, maka dapat diartikan bahwa kebijakan pendanaan berpengaruh secara positif dan signifikan terhadap nilai perusahaan sehingga $\mathrm{H}_{2}$ diterima.

$\mathrm{H}_{3}$ : Profitabilitas berpengaruh terhadap Kebijakan Dividen

Profitabilitas berpengaruh secara positif dan signifikan terhadap kebijakan dividen dengan nilai Original Sample sebesar 0.274, T-Statistik sebesar $2.529>$ nilai T-tabel dan P-Value sebesar 0.012 sehingga $\mathrm{H}_{3}$ diterima. 
$\mathrm{H}_{4}$ : Kebijakan Pendanaan berpengaruh terhadap Kebijakan Dividen

Tabel 2 menunjukkan bahwa antara kebijakan pendanaan terhadap kebijakan dividen memiliki nilai Original Sample sebesar -0.278, T-Statistik sebesar $2.460>$ nilai T-tabel dan P-Value sebesar 0.014, maka dapat diartikan kebijakan pendanaan berpengaruh secara negatif signifikan terhadap kebijakan dividen sehingga $\mathrm{H}_{4}$ ditolak.

$\mathrm{H}_{5}$ : Kebijakan Dividen berpengaruh terhadap Nilai Perusahaan

Nilai Original Sample sebesar -0.004, T-Statistik sebesar $0.059<$ nilai T-tabel, dan P-Value sebesar 0.953 antara kebijakan dividen terhadap nilai perusahaan, maka dapat diartikan bahwa kebijakan dividen berpengaruh secara negatif dan tidak signifikan terhadap nilai perusahaan sehingga $\mathrm{H}_{5}$ ditolak.

$\mathrm{H}_{6}$ : Kebijakan Dividen mampu memediasi Profitabilitas terhadap Nilai Perusahaan

Kebijakan dividen tidak dapat memediasi antara profitabilitas terhadap nilai perusahaan dengan nilai Original Sample sebesar -0.001, T-Statistik sebesar $0.054<$ nilai T-tabel dan P-Value sebesar 0.957 sehingga $\mathrm{H}_{6}$ ditolak.

$\mathrm{H}_{7}$ : Kebijakan Dividen mampu memediasi Kebijakan Pendanaan terhadap Nilai Perusahaan

Kebijakan dividen tidak dapat memediasi antara kebijakan pendanaan terhadap nilai perusahaan dengan nilai Original Sample sebesar 0.001, T-Statistik sebesar $0.071<$ nilai T-tabel dan P-Value sebesar 0.943 sehingga $\mathrm{H}_{7}$ ditolak.

\section{Pengaruh Profitabilitas terhadap Nilai Perusahaan}

Tabel 2 menunjukkan bahwa antara profitabilitas terhadap nilai perusahaan memiliki nilai Original Sample sebesar 0.769, nilai T-Statistik sebesar $12.061>$ nilai T-tabel dan nilai P-Value sebesar 0.000, maka dapat diartikan profitabilitas berpengaruh secara positif dan signifikan terhadap nilai perusahaan sehingga $\mathrm{H}_{1}$ diterima. Hasil dari penelitian ini menunjukkan bahwa semakin tinggi profitabilitas maka semakin tinggi pula nilai perusahaan. Hasil penelitian ini sejalan dengan penelitian yang dilakukan oleh Haryanto dkk. (2018), Indriawati dkk. (2018) dan Hidayat (2019) dalam penelitiannya menghasilkan bahwa profitabilitas berpengaruh secara positif dan signifikan terhadap nilai perusahaan.

\section{Pengaruh Kebijakan Pendanaan terhadap Nilai Perusahaan}

Nilai Original Sample sebesar 0.268, T-Statistik sebesar $3.334>$ nilai T-tabel, dan P-Value sebesar 0.001 antara kebijakan pendanaan terhadap nilai perusahaan, maka dapat diartikan bahwa kebijakan pendanaan berpengaruh secara positif dan signifikan terhadap nilai perusahaan sehingga $\mathrm{H}_{2}$ diterima. Hasil dari penelitian ini menunjukkan bahwa investor percaya semakin tinggi tingkat utang suatu perusahaan maka akan menghasilkan tingkat pengembalian yang tinggi pula. Hasil penelitian ini sejalan dengan penelitian yang dilakukan oleh Jariah (2016) dan Pratiwi \& Mertha (2017) dalam penelitiannya menghasilkan bahwa kebijakan pendanaan berpengaruh secara positif dan signifikan. (Mubyarto \& Khairiyani, 2019) menambahkan kebijakan pendanaan dapat menyebabkan meningkatnya nilai perusahaan karena meminimalkan konflik keagenan. 


\section{Pengaruh Profitabilitas terhadap Kebijakan Dividen}

Profitabilitas berpengaruh secara positif dan signifikan terhadap kebijakan dividen dengan nilai Original Sample sebesar 0.274, T-Statistik sebesar $2.529>$ nilai T-tabel dan P-Value sebesar 0.012 sehingga $\mathrm{H}_{3}$ diterima, maka signalling theory membuktikan bahwa dividen memberikan sinyal mengenai profitabilitas perusahaan karena pembayaran dividen akan meningkatkan keyakinan investor akan keuntungan yang diperoleh perusahaan (Hidayati, 2010). Perusahaan akan meningkatkan dividend payout ratio apabila profitabilitas mengalami peningkatan dan perusahaan merasa mampu mempertahankan peningkatan pendapatan dalam waktu jangka panjang (Sudana, 2011:172).

Hasil penelitian ini sejalan dengan penelitian yang dilakukan oleh Tarmizi \& Agnes (2016), Lestari dkk. (2016) dan Indriawati dkk. (2018) dalam penelitiannya menghasilkan bahwa profitabilitas berpengaruh terhadap kebijakan dividen. Hal tersebut dapat diartikan bahwa profitabilitas menjadi faktor penentu kebijakan dividen, karena pembayaran dividen berasal dari laba bersih yang dihasilkan pada satu periode operasionalnya, semakin besar profitabilitas yang diperoleh perusahaan maka semakin besar pula kapabilitas perusahaan untuk membagikan dividen.

\section{Pengaruh Kebijakan Pendanaan terhadap Kebijakan Dividen}

Tabel 2 menunjukkan bahwa antara kebijakan pendanaan terhadap kebijakan dividen memiliki nilai Original Sample sebesar -0.278, T-Statistik sebesar $2.460>$ nilai T-tabel dan P-Value sebesar 0.014, maka dapat diartikan kebijakan pendanaan berpengaruh secara negatif signifikan terhadap kebijakan dividen sehingga $\mathrm{H}_{4}$ ditolak. Nilai utang yang tinggi menyebabkan pengurangan pada jumlah dividen yang dibagi karena perusahaan lebih mengutamakan membayar utang dan beban-beban daripada dividen. Hasil penelitian ini sejalan dengan penelitian yang dilakukan oleh Supriyanah \& Ghoniyah (2015) dan Utomo (2019) bahwa keputusan pendanaan berpengaruh negatif signifikan terhadap kebijakan dividen.

\section{Pengaruh Kebijakan Dividen terhadap Nilai Perusahaan}

Nilai Original Sample sebesar -0.004, T-Statistik sebesar $0.059<$ nilai T-tabel, dan P-Value sebesar 0.953 antara kebijakan dividen terhadap nilai perusahaan, maka dapat diartikan bahwa kebijakan dividen berpengaruh secara negatif dan tidak signifikan terhadap nilai perusahaan sehingga $\mathrm{H}_{5}$ ditolak, maka membuktikan teori Merton Miller dan Franco Modigliani (MM) yang menjelaskan bahwa nilai perusahaan akan bergantung hanya pada laba yang diproduksi oleh aset-asetnya, bukan pada bagaimana laba tersebut akan dibagi menjadi dividen dan laba tersebut akan ditahan di perusahaan. Hasil penelitian ini sejalan dengan penelitian yang dilakukan oleh Hidayati (2010), Indriawati dkk. (2018) dan Hauteas \& Muslichah (2019) bahwa kebijakan dividen berpengaruh secara negatif dan tidak signifikan terhadap nilai perusahaan.

\section{Peran Kebijakan Dividen dalam Memediasi Profitabilitas terhadap Nilai Perusahaan}

Kebijakan dividen tidak dapat memediasi antara profitabilitas terhadap nilai perusahaan dengan nilai Original Sample sebesar -0.001, T-Statistik sebesar $0.054<$ nilai 
T-tabel dan P-Value sebesar 0.957 sehingga $\mathrm{H}_{6}$ ditolak, maka besar kecilnya profitabilitas yang dihasilkan oleh perusahaan tidak mempengaruhi nilai perusahaan melalui kebijakan dividen. Hasil uji pengaruh langsung antara profitabilitas terhadap nilai perusahaan adalah positif dan signifikan, namun pengaruh langsung antara kebijakan dividen terhadap nilai perusahaan negatif dan tidak signifikan, maka secara tidak langsung profitabilitas belum mampu meningkatkan nilai perusahaan. Hasil penelitian ini sejalan dengan penelitian yang dilakukan oleh Aditya \& Supriyono (2015) dan Jariah (2016) bahwa profitabilitas melalui kebijakan dividen berpengaruh secara negatif dan tidak signifikan terhadap nilai perusahaan.

\section{Peran Kebijakan Dividen dalam Memediasi Kebijakan Pendanaan terhadap Nilai Perusahaan}

Kebijakan dividen tidak dapat memediasi antara kebijakan pendanaan terhadap nilai perusahaan dengan nilai Original Sample sebesar 0.001, T-Statistik sebesar $0.071<$ nilai T-tabel dan P-Value sebesar 0.943 sehingga $\mathrm{H}_{7}$ ditolak, maka besar kecilnya nilai utang yang dimiliki perusahaan tidak mempengaruhi nilai perusahaan melalui kebijakan dividen. Hasil uji pengaruh langsung antara kebijakan pendanaan terhadap nilai perusahaan adalah positif dan signifikan, namun pengaruh langsung antara kebijakan dividen terhadap nilai perusahaan negatif dan tidak signifikan, maka secara tidak langsung kebijakan pendanaan belum mampu meningkatkan nilai perusahaan. Hasil penelitian ini sejalan dengan Supriyanah \& Ghoniyah (2015) bahwa kebijakan dividen tidak mampu memediasi kebijakan pendanaan terhadap nilai perusahaan, namun tidak sejalan dengan penelitian yang dilakukan oleh Jariah (2016) dan Utomo (2019) bahwa kebijakan dividen mampu memediasi kebijakan pendanaan terhadap nilai perusahaan secara positif dan signifikan.

\section{SIMPULAN}

Profitabilitas dan kebijakan pendanaan berpengaruh secara positif dan signifikan terhadap nilai perusahaan, namun kebijakan dividen berpengaruh secara negatif dan tidak signifikan terhadap nilai perusahaan. Hasil dari penelitian ini menunjukkan bahwa semakin tinggi profitabilitas maka semakin tinggi pula nilai perusahaan dan semakin tinggi tingkat utang suatu perusahaan maka akan menghasilkan tingkat pengembalian yang tinggi pula. Sedangkan teori Merton Miller dan Franco Modigliani (MM) menjelaskan bahwa nilai perusahaan akan bergantung hanya pada laba yang diproduksi oleh aset-asetnya, bukan pada bagaimana laba tersebut akan dibagi menjadi dividen dan laba tersebut akan ditahan di perusahaan.

Profitabilitas berpengaruh secara positif dan signifikan terhadap kebijakan dividen. Sedangkan kebijakan pendanaan berpengaruh secara negatif signifikan terhadap kebijakan dividen. Signalling theory membuktikan bahwa dividen memberikan sinyal mengenai profitabilitas perusahaan karena pembayaran dividen akan meningkatkan keyakinan investor akan keuntungan yang diperoleh perusahaan. Dan nilai utang yang tinggi menyebabkan pengurangan pada jumlah dividen yang dibagi karena perusahaan lebih mengutamakan membayar utang dan beban-beban daripada dividen. 
Kebijakan dividen tidak dapat memediasi antara profitabilitas dan kebijakan pendanaan terhadap nilai perusahaan. Besar kecilnya profitabilitas yang dihasilkan dan tingkat utang yang dimiliki oleh perusahaan tidak mempengaruhi nilai perusahaan melalui kebijakan dividen, maka secara tidak langsung profitabilitas dan kebijakan pendanaan belum mampu meningkatkan nilai perusahaan

\section{PUSTAKA ACUAN}

Aditya, D., \& Supriyono, E. (2015). Pengaruh Profitabilitas dan Kepemilikan Institusional terhadap Nilai Perusahaan dengan Kebijakan Dividen sebagai Variabel Intervening pada Perusahaan Manufaktur yang Terdaftar di Bursa Efek Indonesia Periode 20102014. 6(1), 307-326.

Bimo, S. (2013). Uji Outer Model Pada PLS-Path Modeling. http://www.statistikolahdata. com/2013/07/uji-outer-model-pada-pls-path-modeling.html

Brigham, E. F., \& Houston, J. F. (2009). Dasar-dasar Manajemen Keuangan (Edisi Kesepuluh, Buku Satu). Salemba Empat.

Dananjaya, P. M., \& Mustanda, I. K. (2016). Pengaruh Keputusan Investasi, Keputusan Pendanaan dan Kebijakan Dividen Terhadap Nilai Perusahaan pada Perusahaan Manufaktur. E-Jurnal Manajemen Unud, 5(10), 6610-6639.

Fahmi, I. (2014). Manajemen Keuangan Perusahaan dan Pasar Modal. Jakarta: Mitra Wacana Media.

Fuad, M., \& Wandari, A. (2018). Pengaruh Struktur Modal dan Faktor Eksternal terhadap Nilai Perusahaan (Studi pada PT. Bank Central Asia, Tbk). Jurnal Manajemen dan Keuangan, 7(1), 32-46. https://doi.org/10.33059/jmk.v7i1.755

Gitosudarmo, I., \& Basri. (2014). Manajemen Keuangan, Edisi Keempat. Yogyakarta: BPFEYogyakarta.

Hadi, N. (2013). Pasar Modal. Acuan Teoritis dan Praktis Investasi di Instrumen Keuangan Pasar Modal. Yogyakarta: Graha Ilmu.

Haryanto, S., Rahadian, N., Mbapa, M. F. I., Rahayu, E. N., \& Febriyanti, K. V. (2018). Kebijakan Hutang, Ukuran Perusahaan dan Kinerja Keuangan Terhadap Nilai Perusahaan: Industri Perbankan di Indonesia. AFRE (Accounting and Financial Review), 1(2), 62-70. https:// doi.org/10.26905/afr.v1i2.2279

Hauteas, O. S., \& Muslichah. (2019). Analisis Pengaruh Profitabilitas dan Kebijakan Dividen terhadap Nilai Perusahaan dengan Struktur Modal sebagai Variabel Mediasi. Jurnal Manajemen dan Keuangan, 8(2), 177-192.

Hidayat, W. W. (2019). Pengaruh Ukuran Perusahaan, Return On Equity dan Leverage Terhadap Nilai Perusahaan pada Perusahaan Manufaktur di Indonesia. Jurnal Forum Ekonomi, 21(1), 67-75.

Hidayati, E. E. (2010). Analisis Pengaruh DER, DPR, ROE dan SIZE terhadap PBV Perusahaan 
Manufaktur yang Listing di BEI Periode 2005-2007. Jurnal Bisnis STRATEGI, 19(2), 66-174.

Indriawati, I., Ariesta, M., \& Santoso, E. B. (2018). Pengaruh Profitabilitas, Keputusan Investasi, Pertumbuhan Perusahaan Terhadap Nilai Perusahaan dengan Kebijakan Deviden Sebagai Variabel Intervening pada Perusahaan Manufaktur Food And Beverage yang Terdaftar di Bursa Efek Indonesia Tahun 2012-2016. Journal Of Accounting, 1-19.

Jariah, A. (2016). Likuiditas, Leverage dan Profitabilitas Pengaruhnya terhadap Nilai Perusahaan Manufaktur di Indonesia melalui Kebijakan Deviden. Riset Akuntansi dan Keuangan Indonesia, 1(2), 108-118. https://doi.org/10.23917/reaksi.v1i2.2727

Juliandi, A. (2018). Structural equation model based partial least square (SEM-PLS): Menggunakan SmartPLS. Pelatihan SEM-PLS Program Pascasarjana Universitas Batam on December,16-17 2018. Batam: Universitas Batam. https://doi.org/10.5281/ zenodo.2538001

Lestari, K. F., Tanuatmodjo, H., \& Mayasari. (2016). Pengaruh Likuiditas dan Profitabilitas terhadap Kebijakan Dividen. Journal of Business Management Education, 1(2), 11-16.

Mubyarto, N., \& Khairiyani, K. (2019). Kebijakan Investasi, Pendanaan, dan Deviden sebagai Determinan Nilai Perusahaan. Jurnal Akuntansi Multiparadigma, 10(2), 328-341. https:// doi.org/10.18202/jamal.2019.08.10019

Pratiwi, N. P. D., \& Mertha, M. (2017). Pengaruh Kebijakan Hutang dan Profitabilitas pada Nilai Perusahaan dengan Kebijakan Dividen Sebagai Variabel Pemoderasi. E-Jurnal Akuntansi Universitas Udayana, 20(2), 1446-1475.

Priyanto, S. (2016). Pengaruh Kebijakan Dividen, Profitabilitas dan Firm Size terhadap Nilai Perusahaan pada Perusahaan yang tergabung dalam Jakarta Islamic Indeks di Bursa Efek Indonesia. Jurnal Akuntansi dan Keuangan, 5(1), 96-111.

Rakhimsyah, L. A., \& Gunawan, B. (2011). Pengaruh Keputusan Investasi, Keputusan Pendanaan, Kebijakan Dividen dan Tingkat Suku Bunga terhadap Nilai Perusahaan. InFestasi (Jurnal Bisnis dan Akuntansi), 7(1), 31-45. https://doi.org/10.21107/infestasi.v7i1.490

Sudana, I. M. (2011). Manajemen Keuangan Perusahaan: Teori \& Praktik. Jakarta: Erlangga. Sujarweni, V. W. (2014). SPSS untuk Penelitian. Yogyakarta: Pustaka Baru Press.

Sujoko, \& Soebiantoro, U. (2007). Pengaruh Struktur Kepemilikan Saham, Leverage, Faktor Intern dan Faktor Ekstern terhadap Nilai Perusahaan (Studi empirik pada perusahaan manufaktur dan non manufaktur di Bursa Efek Jakarta). Jurnal Manajemen dan Kewirausahaan, 9(1), 41-48.

Supriyanah, \& Ghoniyah, N. (2015). Kebijakan Pendanaan, Insider Ownership dan Firm Size Terhadap Nilai Perusahaan yang Listed Di Bursa Efek Indonesia (BEI) Tahun 2010-2013. Jurnal Ekonomi dan Bisnis, 16(1), 68-79. https://doi.org/10.30659/ ekobis.16.1.68-79 
Tarmizi, R., \& Agnes, T. (2016). Pengaruh Kepemilikan Manajerial, Kepemilikan Institusional, Free Cash Flow dan Profitabilitas Terhadap Kebijakan Dividen pada Perusahaan Manufaktur Go Public yang Terdaftar Di BEI (Periode 2010-2013). Jurnal Akuntansi dan Keuangan, 7(1), Article 1. http://jurnal.ubl.ac.id/index.php/jak/article/view/633

Utomo, M. T. (2019). Pengaruh keputusan pendanaan dan ukuran perusahaan terhadap nilai perusahaan dengan kebijakan dividen sebagai variabel intervening: Studi kasus pada perusahaan manufaktur yang terdaftar di Bursa Efek Indonesia periode 2015-2017 [Undergraduate, Universitas Islam Negeri Maulana Malik Ibrahim]. http://etheses.uinmalang.ac.id/15354/ 